\title{
References
}

Gloss, A., Carr, S. C., Reichman, W., Abdul-Nasiru, I., \& Oesterich, W. T. (2017). From handmaidens to POSH humanitarians: The case for making human capabilities the business of I-O psychology. Industrial and Organizational Psychology: Perspectives on Science and Practice, 10(3), 329-369.

Harpaz, I. (1989). Non-financial employment commitment: A cross-national comparison. Journal of Occupational Psychology, 62, 147-150. doi: 10.1111/j.2044-8325.1989.tb00485.x

Harpaz, I. (2002). Expressing a wish to continue or stop working as related to the meaning of work. European Journal of Work and Organizational Psychology, 11, 177-198. doi: 10.1080/ 13594320244000111

Highhouse, S., Zickar, M. J., \& Yankelevich, M. (2010). Would you work if you won the lottery? Tracking change in the American work ethic. Journal of Applied Psychology, 95, 349-357. doi: $10.1037 / \mathrm{a} 0018359$

Kaplan, H. R., \& Tausky, C. (1974). The meaning of work among the hard-core unemployed. The Pacific Sociological Review, 17, 185-198. doi: 10.2307/1388341

Morse, N. C., \& Weiss, R. S. (1955). The function and meaning of work and the job. American Sociological Review, 20, 191-198. doi: 10.2307/2088325

Snir, R., \& Harpaz, I. (2002). To work or not to work: Nonfinancial employment commitment and the social desirability bias. Journal of Social Psychology, 142, 635-644. doi: 10.1080/ 00224540209603923

Tausky, C. (1969). Meanings of work among blue collar men. The Pacific Sociological Review, 12, 4955. doi: $10.2307 / 1388214$

Terracino, A., Abdel-Khalek, A. M., Adám, N., Adamovová, L, Ahn, C. K., Ahn, H. N., . . McCrae, R. R. (2005). National character does not reflect mean personality trait levels in 48 countries. Science, 310, 96-100. doi: 10.1126/science.1117199

United Nations Development Programme (UNDP). (2014). Human development reports. Retrieved from http://hdr.undp.org

Warr, P. (1982). A national study of non-financial employment commitment. Journal of Occupational Psychology, 55, 297-312. doi: 10.1111/j.2044-8325.1982.tb00103.x

\section{Still Too POSH to Push for Structural Change? The Need for a Macropsychology Perspective}

\author{
Malcolm MacLachlan
}

Maynooth University

My mother, who lived her early years in the British Raj in India, assures me that POSH referred to the well-to-do European's wish to travel "Port Out, Starboard Home" on ships to and from India, which meant enjoying the predominantly shaded side of the ship, protected from the ravaging heat that "ordinary" folk had to endure. What an apt, provocative, and profound analogy Gloss, Carr, Reichman, Abdul-Nasiru, and Oestereich (2017) have given

Malcolm MacLachlan, Department of Psychology, Maynooth University.

Correspondence concerning this article should be addressed to Malcolm MacLachlan, Department of Psychology, Maynooth University, County Kildare, Ireland. E-mail: Mac.MacLachlan@nuim.ie 
us in their description of the primary focus of industrial and organizational (I-O) psychology on "Professional, Official, Secure, and High income" work.

Gloss et al. (2017) call for the charting of new compass points for I-O psychology; theirs is a search for the heart and soul of the discipline-an appeal to turn its bounty of skills and knowledge to address inequity, to serve the impoverish, the marginalized, the exploited-and in so doing, to promote organizational and social justice. Their focal article deserves to be a focus for much reflection and debate within I-O psychology as well as cognate disciplines.

Although one could argue with particulars of the POSH analogy, the empirical operationalization of global data, or the interpretation of their case studies, their general point of a narrow focus of I-O psychology, and the value of it reorientation, is well made and heartening. This commentary, however, argues that Sen's capabilities approach - which Gloss et al. (2017) advocate to be embraced by I-O psychology-is overly individualistic and does not address more fundamental structural and power inequalities, which need to be addressed through the development of a macro perspective, if Gloss et al.'s ambitions are to be realized.

For psychologists, Sen's capability approach (CA) has been a reassuring approach to human development by putting people-their well-being, personal growth and opportunities-before their "economic unit of production" value, which had been the ethos of prior conceptions of international development (Clark, 2009). Sen's (1985) concept of capabilities has been influential in international development, but Dean (2009) argues that it is "essentially a liberal-individualist concept," which does not give sufficient credence to human interdependency, to the public realm, or to the exploitative nature of capitalism. From the point of view of a psychology of organization, the neglect of co-relations is especially problematic. However, it is important to acknowledge that others (e.g., Nussbaum, 2006) have tried to develop this shortcoming of the CA, also acknowledged by Gloss et al. (2017).

In additional to the problematic relational element in CA, it is crucial to recognize that society is organized to resist change and to perpetuate benefits for the more empowered in society-a phenomenon very familiar in the psychological literature on social dominance (Pratto, Stewar, \& Zeineddine, 2013), which has also been applied to the international development contexts discussed by Gloss et al. (e.g., MacLachlan, Carr, \& McAuliffe, 2010). However, for individuals to have real and informed choices-the crux of the CA approach-may often require transformation of the social system in which they live, not only the enhancement of individual capabilities (Dean, 2009). Gloss et al. (2017) give the example of Sati (now rarely practiced) among Hindu communities, where a recently widowed woman burns to death on her husband's funeral pyre. Sen (1985) argues that such practices are wrong 
and that it is permissible for one cultural system to intervene to change the conditions of another cultural system, up to the point-but no further-than for a woman in such circumstances to decide what she herself wants to do.

However, the parameters of such a "choice" are of course constructed by the meta-narratives of religion (in this case) or other societal hegemonic belief systems (Laclau \& Mouffe, 2001). I-O psychology should not therefore endorse a particular interpretation of human rights, as all such interpretations are necessarily time- and culture-bound (McNeilly, 2016). For instance, the United States's Declaration of Independence proclaimed it "to be selfevident, that all men are created equal," which was subsequently contested by women's groups as being inappropriately gendered, which in turn has been contested by LGBTI groups as being inappropriately sexed into a binary. In each case, disempowered groups engaged in political struggle to change how, and to whom, rights were applied.

A widowed woman may indeed "choose" to burn, perhaps due to loyalty to her husband, a sense of familial duty, or from fear that she or her children may be shunned if she does not. Promoting individualistic (or even group) capabilities, while not addressing broader culturally or religiously sanctioned oppression-for instance, of women, people with disabilities, or ethnic minorities-that sets the context for such behaviors, is surely an incomplete approach. In a number of projects, we have used I-O psychology methods to, for instance, advocate for people with disabilities to have more say in the development of Poverty Reduction Strategy Papers ("development plans" produced by low-income countries; MacLachlan et al., 2014), to support the inclusion of marginalized groups in specific social and health policies (Amin et al., 2011), and to facilitate structural change in social institutions (UNPRPD, 2016).

Any attempt to promote organizational justice while addressing the specific capabilities of individuals in specific organizational contexts must also zoom out from the particulars of unfair instances and situations to ask a bigger question: "What system of beliefs, policies, and institutions facilitates unfairness, and is there something that I-O psychology can do about it?" Without doing so, I-O psychology may successfully focus on the proximate symptoms of injustice while eschewing their ultimate causes. Such a response could make I-O psychology unwittingly complicit in their perpetuation, treating symptoms not causes, or even worse, and contrary to Gloss et al.'s (2017) intentions, further marginalizing vulnerable groups.

This "higher-level" perspective is, admittedly, often more associated with other disciplines, particularly political economy analysis (PCA), which addresses three broad issues in the international development context (DFID, 2009): (1) How do the interests and incentives of some (particularly elite) groups influence national development initiatives? (2) How do 
formal and informal social, political, and cultural norms shape human interaction, including political and economic behavior? (3) How do values and ideas-political ideologies, religion, and cultural beliefs-impact political behavior and public policy? These sorts of questions are essentially questions about human behavior in corporate, civil, and government organizations; they are I-O psychology questions. They require a macropsychology perspective (MacLachlan, 2014) to address the settings and conditions in which specific instances of unfairness, injustice, and, indeed, under-performance occur.

To address them, as Gloss et al. (2017) acknowledge, requires I-O psychology to much more strongly question and address power relationships. This must take place both in the workplace and outside it, where policy decisions are taken that directly affect the workplace. I hesitate to say this, but as I write I am on a return flight from Malawi, just having spent time with Malawians working in international development. I heard their exasperation and frustration concerning the dominance of international civil society organizations and United Nations agencies, and often the lack of power of government over its own domain. Such feelings inevitably lead to demotivation, perhaps sometimes disengagement, and sometimes departures from the workplace. Surely this is the stuff of I-O psychology too!

The ethos advocated by Gloss et al. (2017), although necessary and very welcome, is not in itself sufficient to achieve their aims. I-O psychology has much to offer in terms of challenging and changing the social structures and power relations that promote poverty and injustice. However the capability approach does not sufficiently addresses the relational and power dynamics that characterize the broader context of international development. A stronger macro perspective is needed within I-O psychology to allow it to become more engaged in the political economy domain of behavior change.

\section{References}

Amin, M., MacLachlan, M., Mannan, H., El Tayeb, S., El Khatim, A., Swartz, L., ... Schneider, M. (2011). EquiFrame: A framework for analysis of the inclusion of human rights and vulnerable groups in health policies. Health \& Human Rights, 13(2), 1-20.

Clark, D. A. (2009). Adaptation, poverty and well-being: Some issues and observations with special reference to the capability approach and development studies. Journal of Human Development and Capabilities, 10, 21-42. doi: 10.1080/14649880802675051

Dean, H. (2009). Critiquing capabilities: The distractions of a beguiling concept. Critical Social Policy, 29(2), 261-273. doi: 10.1177/0261018308101629

Department for International Development (DFID). (2009). Political economy analysis: How to note. London: Department for International Development.

Gloss, A., Carr, S. C., Reichman, W., Abdul-Nasiru, I., \& Oesterich, W. T. (2017). From handmaidens to POSH humanitarians: The case for making human capabilities the business of I-O psychology. Industrial and Organizational Psychology: Perspectives on Science and Practice, 10(3), 329-369.

Laclau, E., \& Mouffe, C. (2001). Hegemony and socialist strategy: Towards a radical democratic politics. London: Verso. 
MacLachlan, M. (2014). Macropsychology, policy, and global health. American Psychologist, 69, 851863.

MacLachlan, M., Carr, S. C., \& Mc Auliffe, E. (2010). The aid triangle: Recognizing the human dynamics of dominance, justice and identity. London: Zed.

MacLachlan, M., Mji, G., Chataika, T., Wazakili, M., Dube, A. K., Mulumba, M., ... Maughan, M. (2014). Facilitating disability inclusion in poverty reduction processes: Group consensus perspectives from disability stakeholders in Uganda, Malawi, Ethiopia, and Sierra Leone. Disability \& the Global South, 1(1), 107-127.

McNeilly, K. (2016). After the critique of rights: For a radical democratic theory and practice of human rights. Law \& Critique, 27(3), 269-288.

Nussbaum, M. (2006). Frontiers of justice: Disability, nationality, species membership. Cambridge, MA: Harvard University Press.

Pratto, F., Stewart, A. L., \& Zeineddine, F. B. (2013). When inequality fails: Power, group dominance, and societal change. Journal of Social and Political Psychology, 1, 132-160.

Sen, A. (1985). Commodities and capabilities. Amsterdam: Elsevier.

UN Partnership on the Rights of Persons with Disabilities (UNPRPD). (2016). Connections: Building partnerships for disability rights. New York: United Nations Development Programme.

\section{A Missing Link in Gloss et al. ("From Handmaidens to POSH Humanitarians")}

John E. S. Lawrence

Columbia University

Among many salient shifts in international development research over the last few decades has been growing legitimacy in recognition/documentation of the "rise of the South" as noted in the UNDP Human Development Report (2013). This has redirected both research and practice beyond just Northern (read "Western") approaches, opened up new resource flows for "Southern" institutions, and initiated a whole new set of initiatives around "SouthSouth" cooperation (Malik, 2014). To Mahbub ul Haq's original theme of "enlarging people's choices" were added new dimensions of looking beyond just western economies (and solely "economistic" analysis and prescriptions) for solutions to existential threats to sustainable development among the world's poorer nations (UNDP, 1990, p. 9). Fundamental shifts such as these, epitomized in Mahbub's well-known statement on human capacity, ${ }^{1}$ provide the basis for the focal article by Gloss, Carr, Reichman, Abdul-Nasiru, and

John E. S. Lawrence, School of International \& Public Affairs, Columbia University.

Correspondence concerning this article should be addressed to John E. S. Lawrence, School of International \& Public Affairs, Columbia University, 420 W. 118th Street, New York, NY 10027. E-mail: j12323@columbia.edu

1 The real wealth of a nation is its people, and the purpose of development is to create an enabling environment for people to enjoy long, healthy, and creative lives. This simple but powerful truth is too often forgotten in the pursuit of material and financial wealth. 